\title{
EVALUATION OF PARAFFINS BIODEGRADATION AND BIOSURFACTANT PRODUCTION BY BACILLUS SUBTILIS IN THE PRESENCE OF CRUDE OIL
}

\author{
Carmen Lucia Queiroga*; Lídia Regina Nascimento; Gil Eduardo Serra
}

Divisão de Fitoquímica, Centro Pluridisciplinar de Pesquisas Químicas, Biológicas e Agrícolas, Universidade Estadual de Campinas.

Submitted: June 26, 2002; Returned to Authors for corrections: October 09, 2002; Approved: September 15, 2003.

\begin{abstract}
Bacillus subtilis experiments for surface tension evaluation were accomplished with culture medium containing $0.4 \%$ nitrate ions and $4 \%$ glucose basic nutrient in the presence of crude oil. Surfactin production was observed by surface tension reduction of the culture broth. Surfactin was isolated from Bacillus subtilis fermented broth, by acid-precipitation followed by extraction with chloroform-methanol. Evaluation of the linear alkanes composition was performed by capillary gas chromatography. We observed a significant reduction of the surface tension of the fermented broth indicating that the biosurfactant production was not inhibited by the crude oil presence, and that the light paraffins might have been consumed.
\end{abstract}

Key words: Bacillus subtilis, surfactin, surface tension, paraffin, crude oil, gas chromatography.

\section{INTRODUCTION}

In recent years the interest in surface-active agents has increased. Many types of surface-active agents are synthesized by a wide variety of microorganisms and their advantages are biodegradation, low toxicity and low cost (10). Several surfactants produced by different strains of Bacillus have been reported $(6,14)$. Surfactin, also named subtilysin and serolysin, a cyclic lipopeptide produced by some strains of Bacillus subtilis, is the most effective biosurfactant discovered so far (4). Only $20 \mathrm{mg} / \mathrm{L}$ of the purified product reduced the surface tension of water from 72 to $27 \mathrm{mN} / \mathrm{m}$ (10).

A few studies have demonstrated the ability of $B$. subtilis to grow on crude oil and degrade it. Haferburg et al. (6) reported that the addition of hexadecane into culture medium of $B$. subtilis inhibited the synthesis or excretion of surfactin although the biomass increased. Javaheri et al. (9) reported that growth of $B$. licheniformis JF-2 was not inhibited by the presence of crude oil as is $B$. subtilis. Both communications were mentioned by Cooper et al. (4) as reference. However, it is usually postulated that addition of hydrocarbons into a medium enhances the production of biosurfactants by bacteria (4). This incited our interest to evaluate the effect of crude oil on surfactant production by $B$. subtilis. This study also allowed to develop and to optimize methodologies to delineate microbial assays in the presence of crude oil to evaluate biosurfactant production and paraffins biodegradation.

\section{MATERIALS AND METHODS}

\section{Microorganism}

Lyophilized Bacillus subtilis CCT 2576 strain was obtained from the Culture Collection of the Fundação Tropical André Tosello. The microorganism was stored on nutrient agar $(1.5 \mathrm{~g}$ agar, $0.5 \mathrm{~g}$ peptone and $0.3 \mathrm{~g}$ beef extract in $100 \mathrm{~mL}$ water $(\mathrm{pH}$ $7.0)$ ) or in frozen liquid medium ( $0.5 \mathrm{~g}$ peptone and $0.3 \mathrm{~g}$ beef extract in $100 \mathrm{~mL}$ water ( $\mathrm{pH} 7.0)$ ).

\section{Culture conditions}

Shake flasks studies were performed in aerobiosis at $40^{\circ} \mathrm{C}$, $250 \mathrm{rpm}$ in $250 \mathrm{~mL}$ flasks containing $100 \mathrm{~mL}$ of medium and $2 \%$ crude oil. Culture medium and crude oil were autoclaved

*Corresponding author. Mailing address: Divisão de Fitoquímica, Centro Pluridisciplinar de Pesquisas Químicas, Biológicas e Agrícolas, Universidade Estadual de Campinas. Caixa Postal 6171. 13081-970, Campinas, SP, Brasil. E-mail: queiroga@cpqba.unicamp.br 
separately and then mixed. B. subtilis was transfered from liquid medium $\left(0.1 \mathrm{~mL}\right.$ of the activated inoculum for $24 \mathrm{~h}$ at $\left.40^{\circ} \mathrm{C}\right)$ to the following modified mineral salt medium $(4,12): 4 \mathrm{~g} \mathrm{KH}_{2} \mathrm{PO}_{4}, 10 \mathrm{~g}$ $\mathrm{Na}_{2} \mathrm{HPO}_{4} .7 \mathrm{H}_{2} \mathrm{O}, 100 \mathrm{mg} \mathrm{MgSO}$, $1 \mathrm{mg} \mathrm{CaCl}$, $15 \mathrm{mg} \mathrm{Na}$ EDTA, 50 $\mathrm{mg} \mathrm{FeSO}_{4}, 4 \mathrm{~g} \mathrm{NaNO}_{3}, 2 \mathrm{~g} \mathrm{NH}_{4} \mathrm{Cl}, 40 \mathrm{~g}$ glucose (all components per liter of medium). The $\mathrm{pH}$ of the medium was 6.5 . The experiment was performed in triplicate. Uninoculated controls containing the same nutrient formulation were treated identically.

\section{Surfactant isolation}

The biosurfactant was isolated by the modified technique used by Horowitz et al. (7) The culture medium containing biosurfactant was separated from residual crude oil using a separatory funnel. Bacterial cells were removed from culture medium containing surfactant by centrifugation $\left(6300 \mathrm{rpm}, 10^{\circ} \mathrm{C}\right.$, $15 \mathrm{~min})$. The supernatant $(2 \mathrm{~mL})$ was acidified to $\mathrm{pH} 2$ by adding concentrated $\mathrm{HCl}$, allowing the precipitate to settle at $4^{\circ} \mathrm{C}$. The acid precipitate was removed by centrifugation $\left(6000 \mathrm{rpm}, 4^{\circ} \mathrm{C}\right.$, $20 \mathrm{~min}$ ) and $1 \mathrm{~mL}$ acid-water $(\mathrm{HCl}, \mathrm{pH} 2)$ was added. The surfactant was extracted with chloroform-methanol 2:1 (2-3 mL). The organic phase was concentrated and analyzed by TLC.

\section{Thin layer chromatography}

A one-dimensional chromatography (TLC) was performed using silicagel ( $\mathrm{Si} 60 \mathrm{~F}_{254}, 0.2 \mathrm{~mm}$, Merck). The surfactin was dissolved in chloroform and spotted on the TLC plate. The solvent system (4) to develop the plate was chloroformmethanol-25\% ammonium hydroxide $\left(65: 25: 4, R_{f} 0.27\right)$. Spots were visualized by spraying sulfuric acid: methanol (5:85) following heating at $125^{\circ} \mathrm{C}$. Ninhydrin and Rhodamine B were also used to detect spots (8).

\section{Material preparation for liquid chromatography}

To prevent contamination during the analytical procedure, all solvents (Merck, p.a. grade) were distilled in an all-glass system before use. This step was performed using a modification in the technique of Schmitter et al. (13). The silicagel 60 (63-200 $\mathrm{mm}$, Merck) was activated by heating at $350^{\circ} \mathrm{C}$ for $4 \mathrm{~h}$. The vessels were cleaned with ethanolic potassium hydroxide solution (50g $\mathrm{KOH}$ per liter ethanol) followed by rising with water and acetone. Contact of the samples with plastic materials was avoided.

\section{Liquid chromatography}

The residual oil was separated of the fermented broth in a separator funnel. The residual oil in the walls of the separator funnel was recovered by washing with hexane $(30 \mathrm{~mL}, 2 \mathrm{x})$, dried with anhydrous magnesium sulfate, filtered and concentrated in vacuum. A sample $(100 \mathrm{mg})$ of the residual oil was fractionated on silicagel (5.5 g) chromatographic column (1.2 mm i.d.). Saturate hydrocarbons were eluted with hexane $(30 \mathrm{~mL})$, aromatic hydrocarbons with hexane-diethyl ether $(9: 1 ; 30 \mathrm{~mL})$, resins and asphaltenes with chloroform-methanol-water (21:8.4:0.6; $30 \mathrm{~mL})$. The whole culture broth was extracted with hexane $(30 \mathrm{~mL}, 3 \mathrm{x})$ and treated as above to evaluate the soluble hydrocarbons. The saturate hydrocarbons were analyzed by GC.

\section{Gas chromatography}

Saturate hydrocarbons were analyzed using a HP5890 gas chromatograph (FID detector), fitted with retention gap $(1,2,3,5)$ and capillary column HP5 ( $25 \mathrm{~m}$ x $0.2 \mathrm{~mm} \times 0.33 \mathrm{~mm}$ ), with helium as carrier gas $(1.1 \mathrm{~mL} / \mathrm{min})$, a on-column injector and detector temperature $300^{\circ} \mathrm{C}$. Saturate hydrocarbons were analyzed with a temperature programming from $90^{\circ} \mathrm{C}(0.5 \mathrm{~min})-4^{\circ} \mathrm{C} / \mathrm{min}-300^{\circ} \mathrm{C}$ ( $25 \mathrm{~min}.)-5^{\circ} \mathrm{C} / \mathrm{min}-310^{\circ} \mathrm{C}(4 \mathrm{~min}$.$) .$

\section{Surface tension measurements}

The surface tension measurements were done at $25^{\circ} \mathrm{C}$ using a Krüss Tensiometer, Model K10, equipped with plate. The culture broth was separated of the crude oil in a separator funnel, because the presence of oil drops in the broth may affect the readings.

\section{RESULTS}

The optimal growth condition for B. subtilis was reported by Roubin et al. (12). In these assay the growth curve could not be accomplished by optical density because there was an oil emulsion formation in the culture broth. The presence of surfactin, a lipopeptide isolated from the culture medium after growth of B. subtilis, was confirmed by the reduction of the surface tension of the culture broth previously separated of the residual oil, to $25.7 \mathrm{mN} / \mathrm{m}$ (control, $53.0 \mathrm{mN} / \mathrm{m}$ ).

The surface-active compound was isolated from the cellfree supernatant of the culture medium of B. subtilis. The isolation of surfactin was performed by acid precipitation and examined by TLC on silica plates followed by staining with different dye reagents, as described in Materials and Methods. Concentrated sulfuric acid as detection reagent showed the best and faster results $\left(R_{f} 0.27\right.$, chloroform-methanol- $25 \%$ ammonium hydroxide, 65:25:4).

The fermentation was accomplished by surface tension measurements of spent culture liquid and the results are showed in Fig. 1. The surface tension reached the lowest value at the $14^{\text {th }}$ hour of bacterial growth. The medium became viscous and the surface tension reduced to $25.7 \mathrm{mN} / \mathrm{m}$ in relation to uninoculated control, $53.0 \mathrm{mN} / \mathrm{m}$. The surface tension remained close to this low value until the end of the experiment $(27 \mathrm{~h}$ cultivation, ST $25.9 \mathrm{mN} / \mathrm{m}$ ), when the residual oil dispersed into the medium.

In the period between 14-27 $\mathrm{h}$ fermentation occurred a dispersion of the oil, suggesting a change in the original features of the crude oil. It is known that linear hydrocarbons can be the first ones to be utilized by microorganisms. To evaluate the nalkanes utilized by $B$. subtilis it was necessary to fractionate 


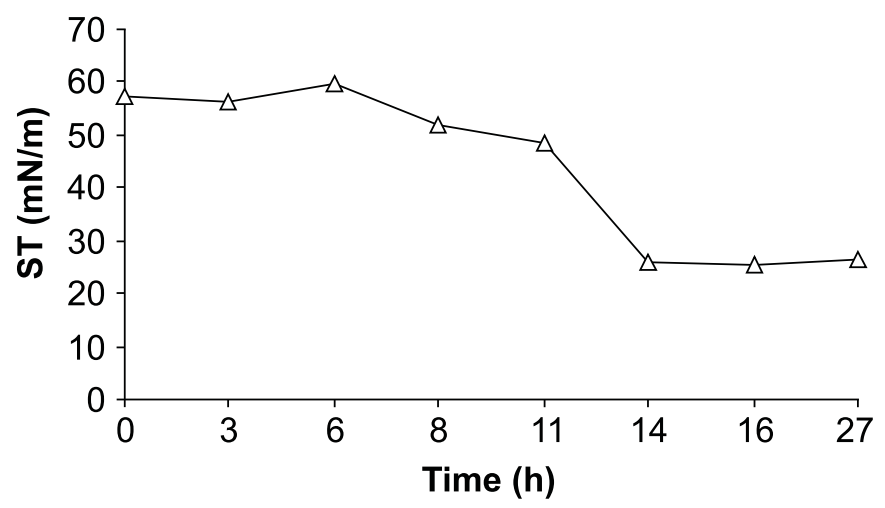

Figure 1. Surface tension ( $\mathrm{ST}$ in $\mathrm{mN} / \mathrm{m}$ ) values of the culture medium of $B$. subtilis fermentation.

the residual oil. The liquid chromatography for crude oil is well known (11). However, nowadays some modifications are done, as described in Materials and Methods. The results of liquid chromatographic analysis of the crude oil (control) and the residual oil after growth of $B$. subtilis, recovered by density, are presented in Table 1.

The basic chemical composition of the samples (Table 1) showed no expressive change. The dissolved oil in the culture broth was recovered by solvent extraction. The amount of dissolved oil after $27 \mathrm{~h}$ fermentation was $62 \mathrm{mg}$, which is relatively insignificant compared to the weight of the crude oil $(2 \mathrm{~g})$ used in the experiment. However the saturated hydrocarbon composition can be an indication of biodegradation occurrence. The $\mathrm{n}$-alkanes depletion by the bacteria employed could not be visualized by liquid chromatography separation, weighting the fractions of saturate hydrocarbons, however, the bacterial activity on crude oil was observed by gas chromatography. The chromatogram profile of saturate hydrocarbons of $27 \mathrm{~h}$ fermentation sample can be compared with the saturate hydrocarbons fraction from control sample in Fig. 2.

Table 1. Chemical composition of oil by liquid chromatographic analysis.

\begin{tabular}{|c|c|c|c|c|}
\hline \multirow{3}{*}{ Oil fraction } & \multicolumn{4}{|c|}{$\%$ Weight } \\
\hline & \multirow[t]{2}{*}{ Control } & \multicolumn{2}{|c|}{ Fermentation } & \multirow{2}{*}{$\begin{array}{l}\text { Oil extracted from } \\
\text { culture broth after } \\
27 \mathrm{~h} \text { fermentation by } \\
\text { B. subtilis }\end{array}$} \\
\hline & & $14 \mathrm{~h}$ & $27 \mathrm{~h}$ & \\
\hline $\begin{array}{l}\text { Saturate } \\
\text { hydrocarbons }\end{array}$ & 79.2 & 77.7 & 78.4 & 79.7 \\
\hline $\begin{array}{l}\text { Aromatic } \\
\text { hydrocarbons }\end{array}$ & 15.8 & 16.5 & 16.5 & 15.0 \\
\hline $\begin{array}{l}\text { Resins and } \\
\text { Asphaltenes }\end{array}$ & 5.0 & 5.8 & 5.1 & 5.3 \\
\hline
\end{tabular}

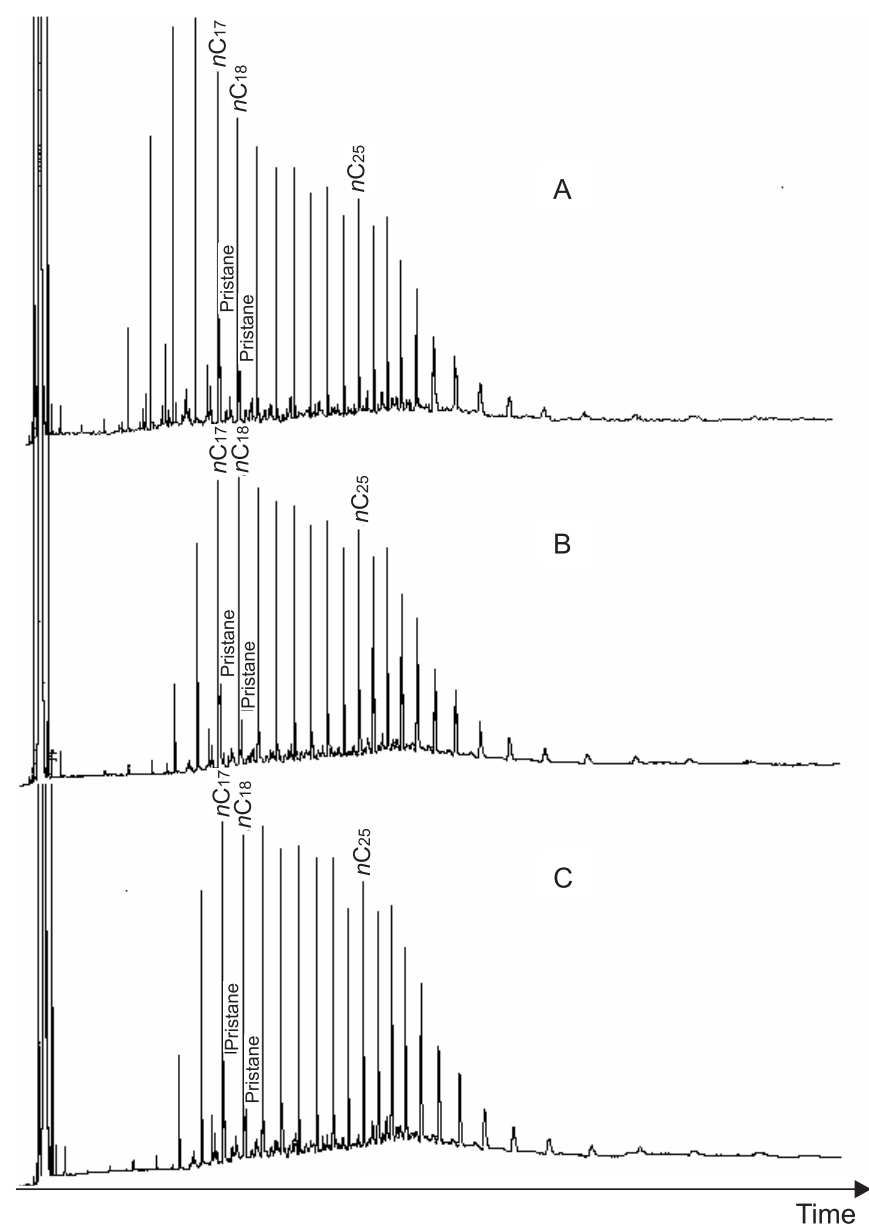

Figure 2. Gas chromatographic analysis of saturate hydrocarbons fractions. (A) Profile of saturate hydrocarbons from uninoculated control, crude oil. (B) Profile of saturate hydrocarbons fraction of residual oil after $27 \mathrm{~h}$ aerobic growth of B. subtilis. (C) Profile of saturate hydrocarbons of oil dissolved in culture broth.

In the chromatogram profile (B) a decrease of the low molecular weight $n$-alkanes $\left(\mathrm{C}_{14}-\mathrm{C}_{17}\right)$ is observed. If these alkanes had been dissolved in culture broth, an increase of $\mathrm{n}$ alkanes $\left(\mathrm{C}_{14}-\mathrm{C}_{17}\right)$ in the chromatogram profile $(\mathrm{C})$ would be expected. In this investigation, the ratio between the area of each individual peak and the total paraffins area (from $\mathrm{C}_{14}$ to $\mathrm{C}_{33}$ plus Pristan plus Phytan) were calculated and the results are shown in Fig. 3.

The comparison of the each individual component of the residual oil after $27 \mathrm{~h} \mathrm{~B}$. subtilis fermentation showed $95 \%$ reduction for $\mathrm{C}_{14}, 72 \%$ for $\mathrm{C}_{15}, 31 \%$ for $\mathrm{C}_{16}$ and $3.5 \%$ for $\mathrm{C}_{17}$ in the saturated hydrocarbon fraction in relation to the control. This reduction is visible in Fig. 3. The saturated hydrocarbon fraction of the soluble oil extracted from culture broth showed 


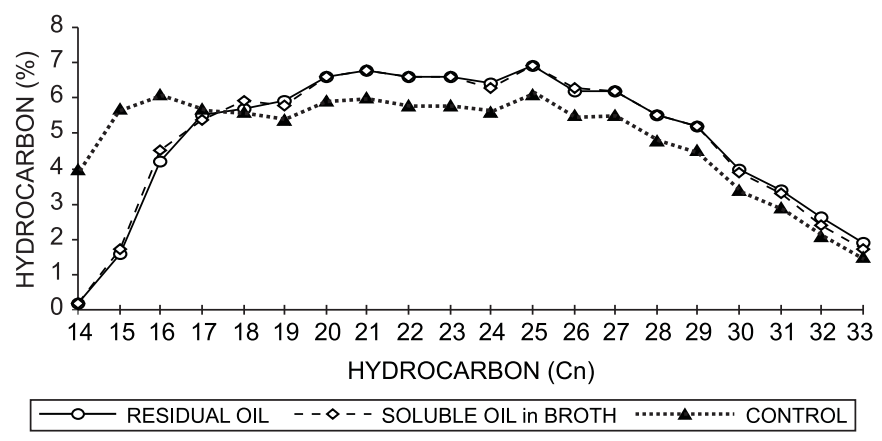

Figure 3. Quantitative analysis of saturate fractions (paraffins) of the samples: crude oil (control), residual oil and soluble oil in the culture broth.

$95,70,26$ and $5 \%$ reduction, respectively. In contrast to low molecular weight n-alkanes $\left(\mathrm{C}_{14}-\mathrm{C}_{17}\right)$ reduction there was an increase of the long-chain saturated components, 12 to $17 \%$ for $\mathrm{C}_{20}-\mathrm{C}_{31}$. It indicates that the low molecular weight n-alkanes $\left(\mathrm{C}_{14}-\mathrm{C}_{17}\right)$ might have been preferentially utilized as secondary carbon and energy sources.

The data presented in this paper indicate that the crude oil presence in the medium culture showed no inhibitory effect on biosurfactant production by $B$. subtilis and that a biodegradation of low molecular weight n-alkanes $\left(\mathrm{C}_{14}-\mathrm{C}_{17}\right)$ might have occurred. However, if a biodegradation happened it was not significant.

\section{ACKNOWLEDGEMENTS}

The authors wish to thank for RHAE/CNPq and FAPESP for financial support.

\section{RESUMO}

\section{Avaliação da biodegradação de parafinas e da produção de biosurfactante por Bacillus subtilis na presença de petróleo}

Os experimentos com Bacillus subtilis para avaliação da tensão superficial foram realizados com meio de cultivo contendo como nutrientes básicos $0,4 \%$ de ions nitrato e $4 \%$ de glicose, na presença de petróleo. A produção de surfactina foi observada pela redução da tensão superficial do meio de cultura fermentado. Surfactina foi isolada a partir do meio de cultura fermentado por B. subtilis, por precipitação ácida seguida de extração com clorofórmio-metanol. A avaliação da composição dos alcanos lineares (parafinas) foi realizada por cromatografia gasosa. Observamos uma significativa redução da tensão superficial do meio de cultura indicando que a produção de biosurfactante não foi inibida pela presença de parafina, e que as parafinas leves podem ter sido consumidas.

Palavras-chave: Bacillus subtilis, surfactina, tensão superficial, parafinas, petróleo, cromatografia gasosa.

\section{REFERENCES}

1. Aquino Neto, F.R.; Cardoso, J.N. Lacunas de retenção em cromatografia gasosa de alta resolução. Química Nova, 15:224-227, 1992.

2. Aquino Neto, F.R.; Cardoso, J.N. Seleção de colunas e condições de análise em cromatografia gasosa de alta resolução. Química Nova, 11:275-284, 1988.

3. Cardoso, J.N.; Aquino Neto, F.R. Testes de avaliação de colunas capilares para cromatografia gasosa com fase de alta resolução. Química Nova, 9:58-63, 1986.

4. Cooper, D.G.; MacDonald, C.R.; Duff, S.J.B.; Kosaric, N. Enhanced production of surfactin from Bacillus subtilis by continuous product removal and metal cation additions. Appl. Environ. Microbiol., 42:408-412, 1981.

5. Grob Jr., K. Band boadening space and the retention gap in capillary gas chromatography. J. Chromatography, 237:15-23, 1982.

6. Haferburg, D.; Hommel, R.; Claus, R.; Kleber, H.P. Extracellular microbial lipids as biosurfactants. Adv. Biochem. Eng., 33:53-93, 1986.

7. Horowitz, S.; Gilbert, J.N.; Griffin, W.M. Isolation and characterization of a surfactant produced by Bacillus licheniformis 86. J. Ind. Microbiol., 6:243-248, 1990.

8. Horowitz ,S.; Griffin, W.M. Structural analysis of a Bacillus licheniformis 86 surfactant. J. Ind. Microbiol., 7:45-52, 1991.

9. Javaheri, M.; Jenneman, G.E.; McInerney, M.J.; Knapp, R.M. Anaerobic production of a biosurfactant by Bacillus licheniformis JF-2. Appl. Environ. Microbiol., 50:698-700, 1985.

10. Jenny, K.; Käppeli, O.; Fichter, A. Biosurfactants from Bacillus licheniformis: structural analysis and characterization. Appl. Microbiol. Biotechnol., 57:5-13, 1991.

11. Jobson, A.; Cook, F.D.; Westlake, D.W.S. Microbial utilization of crude oil. Appl. Microbiol., 23:1082-1089, 1972.

12. Roubin, M.R.; Mulligan, C.N.; Gibbs, B.F. Correlation of enhanced surfactin production with decreased isocitrate dehydrogenase activity. Can. J. Microbiol., 35:854-859, 1989.

13. Schmitter, J.M.; Arpino, J.M.; Guiochon, G. Investigations of highmolecular-weight carboxylic acids in petroleum by different combinations of chromatography (gas and liquid) and mass spectroscopy (electron impact and chemical ionization). J. Chromatography, 167:149-158, 1978.

14. Zajic, J.E.; Mahomedy, A.Y. Biosurfactants: intermediates in the biosynthesis of amphiphathic molecules in microbes. In: Atlas, R.M. (ed.) Petroleum Microbiology. Macmillan Publishing Company, New York, 1984, p.221-297. 